\title{
PERILAKU KOMUNIKASI KELOMPOK KOMUNITAS VIRTUAL KASKUS REGIONAL RIAU RAYA
}

\author{
Nova Yohana \\ Fakultas Ilmu Sosial Ilmu Politik, Jurusan Komunikasi, Universitas Riau, Pekanbaru- 28293 \\ Telp/Fax/HP (0761) 632677, 35675, 081320033210.Email: nova.yo7@gmail.com \\ Tika Wulandari \\ Fakultas Ilmu Sosial Ilmu Politik, Jurusan Komunikasi, Universitas Riau, Pekanbaru- 28293 \\ Telp/Fax/HP (0761) 632677, 35675, 081320033210 \\ Email: thyca_906200f@yahoo.com \\ Naskah dikirim tanggal 23 September 2014, direvisi tanggal 13 November 2014, disetujui tanggal 25 November \\ 2014
}

\section{COMMUNICATION GROUPS BEHAVIOUR OF KASKUS VIRTUAL COMMUNITY OF RIAU RAYA REGION}

\begin{abstract}
The development of internet which grew rapidly has given rise to virtual communities among others such as the Kaskus Community of Riau Raya Region. In this community a new form of social space was created that influence the interaction and communication behavior among its members. This study aimed to determine the role of communicator of the virtual group, the interchangeable messages, the interaction patterns, the unity and norms of group communication in Kaskus virtual community of Riau Raya Region in Pekanbaru. The qualitative method was employed using symbolic interaction approach and the instruments used to collect the data were observation, interview and documentation. The result of the study showed that the member of Kaskus virtual community of Riau Raya has a role in accordance with the structure and the level of the post. As a forum for discussion and trading, the members of this community share information using Kaskus language as the group identity. Social interaction that exist in this community is not only happening in online communication but also offline communication.
\end{abstract}

Keywords: group communication, virtual community, Riau Raya Regional Kaskus, Symbolic Interaction.

\begin{abstract}
Abstrak
Perkembangan dunia internet yang semakin pesat meningkatkan lahirnya komunitas-komunitas virtual salah satunya Komunitas Kaskus Regional Riau Raya. Pada Komunitas Kaskus Regional Riau Raya terbentuk ruang sosial baru yang memengaruhi perilaku interaksi dan komunikasi antaranggota kelompok. Penelitian ini bertujuan untuk mengetahui peran dari pelaku komunikasi kelompok virtual, pesan-pesan yang dipertukarkan, pola interaksi, dan kohesivisitas serta norma komunikasi kelompok dalam Komunitas Virtual Kaskus Regional Riau Raya di Kota Pekanbaru. Metode yang digunakan adalah metode kualitatif dengan pendekatan Interaksi Simbolik. Data dikumpulkan melalui observasi, wawancara, dan dokumentasi. Hasil penelitian menunjukkan bahwa anggota Komunitas Virtual Kaskus Regional Riau Raya memiliki peran sesuai dengan struktur dan tingkatan postingan. Sebagai forum diskusi dan forum jual beli anggota Komunitas Virtual Kaskus Regional Riau Raya saling berbagi informasi dengan menggunakan ragam bahasa kaskus sebagai identitas kelompok. Interaksi sosial yang terjalin di
\end{abstract}


Komunitas Kaskus Regional Riau Raya tidak hanya berlangsung secara komunikasi online tetapi juga offline.

Kata kunci: komunikasi kelompok, komunitas virtual, Kaskus Regional Riau Raya, Interaksi Simbolik.

\section{PENDAHULUAN}

Perkembangan internet pada era sekarang ini menyebabkan lahirnya era cyber society (masyarakat maya) dan virtual community (komunitas virtual). Kaskus adalah sebuah situs forum komunitas virtual terbesar dan nomor satu di Indonesia dengan tagline The Largest Indonesian Community dan memunyai alamat website http://www.kaskus.co.id. Kaskus yang berasal dari kata kasak kusuk sangat digemari karena kemampuannya dalam mengakomodasi hampir semua kebutuhan, keinginan,dan minat dari para surfer internet. Komunitas ini menyediakan forum yang membahas segala hal, mulai topik politik yang serius hingga topik yang sangat ringan dan remeh. Komunitas ini juga menyediakan forum jual beli (FJB) yang memungkinkan pengguna internet untuk berjual beli mulai dari barang yang bernilai puluhan ribu hingga tanah yang berharga ratusan juta rupiah (Pramiyanti dan Cristin, 2014).

Kaskuser adalah sebutan bagi para pengguna kaskus. Umumnya kaskuser ini berasal dari berbagai latar belakang, sifat, dan daerah yang berbeda-beda dan mulai menjalin komunikasi dan pertemanan melalui beberapa forum atau kategori-kategori yang terdapat di kaskus. Para kaskuser terkenal dengan kesolidan dan kekompakan mereka, tidak hanya sekedar menjadi pengikut (follower) dari satu atau beberapa kategori yang ada di dalam kaskus, tetapi para kaskuser juga berinisiatif menciptakan kelompok mereka sendiri. Oleh karena itu tidak heran muncul beberapa komunitas kaskuser yang dibuat oleh kaskuser-kaskuser yang berasal dari asal atau daerah yang sama. Salah satunya adalah Komunitas Kaskus Regional Riau Raya.

Menjadi anggota Kaskus di dunia maya belum tentu menjadi anggota Kaskus Regional Riau Raya. Ada beberapa langkah yang perlu diikuti kaskuser yang juga ingin menjadi kaskuser Kaskus Regional Riau Raya. Setelah memunyai account Kaskus, anggota masuk ke dalam sub-forum Kaskus Regional Riau Raya. Di sana kaskuser mendaftarkan diri menjadi anggota dengan mengisi formulir yang ada di top thread Regional Riau Raya. Setelah mengisi formulir beserta foto, kaskuser bisa menuliskan comment perkenalan di thread tersebut. Anggota Komunitas Kaskus Regional Riau Raya berdasarkan data yang di kirim para kaskuser melalui pencarian situs web kaskus.co.id, berjumlah 414 orang. Para anggota tinggal di Riau pada umumnya, dan yang lain merupakan perantauan.

Komunitas Kaskus Regional Riau Raya tidak hanya sekedar sebuah komunitas yang berkomunikasi melalui dunia maya saja. Eksis di dunia maya tak membuat para kaskuser berhenti sampai di situ. Setelah malang-melintang di dunia online, mereka juga melakukan kegiatan offline yang mewadahi kegiatan non online mereka untuk saling mengenal dan mempererat keakraban antaranggota dengan mengadakan kegiatankegiatan sosial dan peduli lingkungan seperti bakti sosial, menjadi relawan bencana, donor darah, mengunjungi panti asuhan, penanaman pohon, dan kegiatan kebersamaan lainnya seperti CFD (Car Free Day), futsal, buka bersama, nonton bareng, gathering akbar, dan mini gathering. Kegiatan-kegiatan offline yang bersifat sosial dilaksanakan dengan struktur panitia yang jelas, serta memiliki Field Report (laporan kegiatan) paska kegiatannya yang diposting di sub forum Kaskus Regional Riau Raya (Profil Kaskus Regional Riau Raya, 2013). Dalam realitas interaksi komunikasi kelompok yang terdapat di Komunitas Virtual Kaskus Regional Riau Raya baik aktivitas online dan offline, mereka berinteraksi dan berkomunikasi dengan penggunaan ragam bahasa khusus yang mewakili kelompoknya. Merlina (2013) mengatakan bahwa Kaskus is 
a forum in the internet which has grown to be one of the most popular websites in Indonesia. They have their characteristic and the member mostly as a language of comunication. Dalam hal ini Kaskuser Regional Riau Raya memiliki bahasa tersendiri untuk berkomunikasi yang pada perkembangannya menjadi trend di pengguna dunia maya. Bahasa-bahasa itu, seperti kata sapaan Agan dan Aganwati, istilah Pertamax, Cendol, Bata, Afgan, COD, dan lain-lain. Selain itu mereka juga memanggil nama kaskuser lainnya dengan menggunakan kaskus ID masing-masing yang memiliki makna tersendiri bagi mereka dan membuat mereka merasa semakin dekat satu sama lain. Fungsi bahasa kaskus yang paling inti adalah sebagai identitas kelompok dan sarana meningkatkan solidaritas kelompok. Hal inilah yang menjadi salah satu keunikan Komunitas Kaskus Regional Riau Raya sebagai virtual community (komunitas virtual).

Suatu komunitas pasti memiliki keinginan untuk membedakan dirinya dengan komunitas lain. Komunitas sendiri diartikan sebagai sebuah kelompok sosial dari beberapa organisme yang berbagi lingkungan umumnya memiliki ketertarikan dan habitat yang sama. Seperti halnya komunitas lainnya komunitas virtual merupakan sekumpulan individu yang di dalamnya memiliki maksud, kepercayaan, sumber daya, preferensi, kebutuhan, risiko, dan sejumlah kondisi lain yang serupa (Wenger, 2002). Melalui komunitas ini setiap individu dapat mencoba untuk mengetahui karakteristik tentang setiap individu. Kecepatan informasi dan kedalaman aplikasi sistem tekonologi yang sangat tinggi yang sekarang ini menjadikan virtual community sebagai budaya yang digemari oleh para peminatnya. Sebuah komunitas virtual akan membentuk ruang sosial baru.

Berdasarkan uraian tersebut di atas dapat dikemukakan pertanyaan yang mendasari penelitian ini yakni: Bagaimana peran dari pelaku komunikasi kelompok pada Komunitas Virtual Kaskus Regional Riau Raya? Bagaimana pesan-pesan yang dipertukarkan dalam komunikasi kelompok Komunitas Kaskus Regional Riau Raya?
Bagaimana pola interaksi yang terjadi di dalam komunikasi kelompok Komunitas Kaskus Regional Riau Raya? Bagaimana kohesivitas atau keeratan anggota kelompok di Komunitas Virtual Kaskus Regional Riau Raya? Bagaimana norma yang digunakan di dalam Komunitas Kaskus Regional Riau Raya?

Tujuan penelitian ini adalah untuk memeroleh gambaran lengkap tentang peran dari pelaku komunikasi kelompok, pesanpesan yang dipertukarkan, pola interaksi yang terjadi, kohesivistas atau keeratan anggota kelompok dan norma yang digunakan di dalam perilaku komunikasi kelompok Komunitas Virtual Kaskus Regional Riau Raya. Kontribusi yang didapatkan dari penelitian ini adalah menambah pengembangan teoretis terhadap kajian komunikasi kelompok pada komunitas virtual melalui interaksionisme simbolik. Pada sisi lain hasil penelitian dapat memberikan gambaran pola interaksi dan komunikasi pada komunitas virtual dalam membentuk kohesivitas kelompok.

\section{LANDASAN KONSEP}

\section{Penelitian Terdahulu}

Sejumlah penelitian tentang perilaku komunikasi kelompok virtual sudah banyak dilakukan di antaranya adalah penelitian yang dilakukan Diradametha, N. (2009) dalam Skripsi Universitas Indonesia dengan judul "Pembentukan Identitas pada Komunitas Virtual: Studi Kasus Komunitas Virtual Archangel" mengungkap perbedaan komunitas virtual yang terjadi di Indonesia dengan komunitas virtual di negara lain. Hubungan antara individu dalam komunitas virtual di Indonesia lebih didasarkan pada hubungan di luar jaringan informasi atau dalam kasus ini hubungan pertemanan.

Penelitian lainnya dilakukan oleh Susilo (2011) dalam Digital Colections Petra Christian University (2012) dengan judul Proses Interaksi Kelompok Virtual Global A-Melody. Hasil penelitian menyatakan bahwa A-Melody mampu berinteraksi melalui tahapan peripheral dan 
central dengan baik. Pada akhirnya kepercayaan dalam kelompok tersebut muncul dan berkembang. Kepercayaan tersebut berwujud kelompok yang kompak, masing-masing anggota saling memaklumi keadaan yang lain, masing-masing anggota selalu memberikan kontribusi positif pada setiap projek, masing-masing anggota memiliki sifat loyal dan mampu menjaga kohesivitas dan eksistensi kelompok mereka.

\section{Kelompok dan Perilaku Komunikasi}

Kelompok adalah sekumpulan orang yang memunyai tujuan bersama dan yang berinteraksi satu sama lain untuk mencapai tujuan bersama, mengenal satu sama lainnya, dan memandang mereka sebagai bagian dari kelompok tersebut (Mulyana, 2008). Menurut Johnson dan Johnson dalam Derry (2005), komunikasi kelompok dapat lebih bisa dipahami sebagai suatu pola interaksi daripada sebagai suatu rangkaian keterampilan khusus.

Sebuah kelompok yang melakukan komunikasi akan menimbulkan perilaku komunikasi. Menurut Gould dan Kolb seperti dikutip oleh Ichwanudin (1998), perilaku komunikasi adalah segala aktivitas yang bertujuan untuk mencari dan memeroleh informasi dari berbagai sumber dan untuk menyebarluaskan informasi kepada pihak manapun yang memerlukan. Perilaku komunikasi pada dasarnya berorientasi pada tujuan dalam arti perilaku seseorang pada umumnya dimotivasi dengan keinginan untuk memeroleh tujuan tertentu. Perilaku komunikasi dalam kelompok adalah tindakan dalam berkomunikasi (Khairil, 2012).

\section{Komunikasi Kelompok dan Perkembangan Teknologi Komunikasi}

Komunikasi kelompok berkembang sejalan dengan perkembangan teknologi komunikasi yang terjadi untuk mengatasi perbedaan jarak yang jauh yang tidak dicapai hanya dengan berbicara dalam jarak yang normal. McLuhan mengatakan bahwa perubahan yang terjadi pada berbagai macam cara berkomunikasi akan membentuk pula keberadaan atas manusia itu sendiri (Muslimin, 2010).
Penggunaan teknologi ataupun media komunikasi seperti ini telah menjadi sebuah kebutuhan pokok bagi pelaku komunikasi saat ini, karena pada hakikatnya semua orang berkepentingan untuk menjalin hubungan harmonis dengan orang lain dengan menggunakan media yang relevan (Muslimin, 2010). Dengan kenyataan ini perkembangan konektivitas individu dengan individu atau seseorang dengan seseorang, lebih dipengaruhi oleh perkembangan teknologi komunikasi dari pada teknologi transportasi (Suparno, Sosiawan,dan Tripambudi, 2012).

\section{Komunitas Virtual}

Tanpa disadari, komunitas manusia telah hidup dalam dua dunia kehidupan, yaitu kehidupan nyata dan kehidupan masyarakat maya (cybercommunity) (Bungin, 2011). Bahkan hal ini kemudian menjadikan manusia (baik secara individu maupun kelompok) lebih tertarik untuk berkomunikasi di dunia maya. Komunitas seperti ini kemudian dikenal sebagai komunitas virtual. Komunitas virtual adalah sekumpulan pengguna internet yang membentuk jaringan hubungan personal (Spaulding, 2009).

Rheingold (2000), menjelaskan "virtual communities are social aggregations that emerge from the net when enough people carry on those public discussions long enough, with sufficiet human feeling, to form webs of personal realtionship in cyberspace." Sedangkan Wood dan Smith (2005) menjelaskan virtual community sebagai "A shared understanding of interrelatedness among participants in computer-mediated environments." Dapat ditarik sebuah kesimpulan bahwa virtual communities atau komunitas virtual adalah kumpulan pengguna/user yang dibentuk secara online di mana masing-masing menggunakan identitas nyatu atau rekaan (avatar) serta informasi online tertentu untuk melakukan komunikasi atau interaksi secara terus-menerus melalui mediasi jaringan komputer (Nasrullah, 2012).

\section{Interaksionisme Simbolik}

Teori Interaksionisme Simbolik memelajari sifat interaksi yang merupakan 
kegiatan sosial dinamis manusia. Bagi perspektif ini, individu bersifat aktif, reflektif, dan kreatif, menafsirkan, menampilkan perilaku yang rumit dan sulit diramalkan. (West dan Turner, 2008).

Menurut teoretisi Interaksi Simbolik, kehidupan sosial pada dasarnya adalah interaksi manusia dengan menggunakan simbol-simbol. Mereka tertarik pada cara manusia menggunakan simbol-simbol yang mempresentasikan apa yang mereka maksud untuk berkomunikasi dengan sesamanya, dan juga pengaruh yang ditimbulkan penafsiran atas simbol-simbol ini terhadap perilaku pihak-pihak yang terlibat dalam interaksi sosial. Penganut Interaksionisme Simbolik berpandangan, perilaku manusia pada dasarnya adalah produk dari interpretasi mereka atas dunia di sekeliling mereka, perilaku dipilih sebagai sesuatu yang layak dilakukan berdasarkan cara individu mendefinisikan situasi yang ada (Mulyana, 2010).

Dari uraian tersebut, penulis mencoba menggambarkan kerangka pemikiran penelitian ini ke dalam suatu model seperti pada gambar 1 .

\section{METODE PENELITIAN}

Dalam penelitian ini metode yang digunakan adalah metode kualitatif dengan pendekatan Interaksi Simbolik. Penelitian kualitatif merupakan penelitian yang memanfaatkan wawacara terbuka untuk menelaah dan memahami sikap, pandangan, perasaan dan perilaku individu atau kelompok orang (Moleong, 2008). Dalam penelitian ini, peneliti menggunakan pendekatan Interaksi Simbolik untuk memahami makna interaksi dan komunikasi melalui pertukaran simbolsimbol yang terjadi dalam Komunitas Virtual Kaskus Regional Riau Raya baik pada komunikasi online maupun offline.

Teknik pemilihan informan yang digunakan dalam penelitian ini adalah dengan sampling purposif yakni memilih informan berdasarkan kriteria yang dianggap memenuhi tujuan penelitian yang ditunjukkan pada tabel 1. Teknik pengumpulan data menggunakan wawancara (indepth interviews), observasi, dokumentasi dan studi pustaka.



Gambar 1

Kerangka Pemikiran 
Tabel 1

Informan Penelitian

\begin{tabular}{|c|c|c|c|c|c|}
\hline NO & $N A M A$ & USIA & PEKERJAAN & KASKUS ID & STATUS \\
\hline 1. & Andrew Pradana & 29 th & PNS & scoty_and & $\begin{array}{l}\text { Regional } \\
\text { Leader Riau } \\
\text { Raya. }\end{array}$ \\
\hline 2. & Alman Faluti & 35 th & Wiraswasta & alman_cell & $\begin{array}{l}\text { Aktivis } \\
\text { Regional Riau } \\
\text { Raya. }\end{array}$ \\
\hline 3. & Monalisa Dewi Ayu & 22 th & Mahasiswi & asilanom & $\begin{array}{l}\text { Aktivis } \\
\text { Regional Riau } \\
\text { Raya. }\end{array}$ \\
\hline 4. & Suseno Aji Suryana & 21 th & Mahasiswa & bboyseno & Kaskus Geek. \\
\hline 5. & Muhammad Rijal & 21 th & Mahasiswa & exdjailmud & Kaskus Donatur \\
\hline
\end{tabular}

Sumber: hasil wawancara 2013.

Dalam hal memahami secara mendalam maksud-maksud dari simbol yang dilakukan para kaskuser dalam melakukan interaksi, peneliti terlibat langsung dalam kegiatankegiatan yang dilakukan Komunitas Kaskus Regional Riau Raya serta mendaftarkan diri menjadi anggota resmi guna pendeskripsian pengamatan (observasi) secara lebih jelas. Analisis data yang digunakan melalaui tiga komponen yaitu reduksi data, sajian data, dan penarikan kesimpulan serta verifikasi.

\section{HASILPENELITIAN DAN PEMBAHASAN}

\section{Peran Pelaku Komunikasi Kelompok Komunitas Virtual Kaskus Regional Riau Raya}

Dalam sebuah komunitas vrtual, seperti halnya dalam sistem sosial di masyarakat yang terdapat peran-peran yang muncul. Kaskus Regional Riau Raya dipimpin oleh seorang regional leader yang proses pemilihannya melalui pemilu/voting offline komunitas. Regional leader sendiri dibantu oleh tiga orang Aktivis Regional. Regional leader selain berperan besar dalam pengambilan keputusan, regional leader juga berwenang membantu menyelesaikan konflik antarKaskuser Regional Riau Raya, yang tidak mampu mereka menyelesaikan secara pribadi. Regional leader, diwajibkan memonitor seluruh thread yang masuk ke dalam subforum Kaskus Regional Riau Raya. Tidak hanya memonitor, juga harus menjaga hubungan dengan kaskuser lainnya, salah satu caranya yaitu dengan sering melakukan komunikasi virtual.

Aktivis regional juga bisa turut mengambil peran dalam penyelesaian konflik ini, jika regional leader memberikan wewenang pada mereka. Permasalahan yang umumnya terjadi ialah, kesalahan salah satu kaskuser dalam penyampaian pesan di forum online yang berbuntut pada kesalahpahaman kaskuser lainnya. Meskipun memiliki struktur dan tingkatan, namun setiap anggota Kaskus Regional Riau Raya memiliki hak suara yang sama ketika berkomunikasi. Sebagaimana dikatakan oleh Andrew:

"Sah-sah aja kalo ada kaskuser yang mau bicara sama saya di forum, mereka bisa ngirim PM (Private Massage) ke saya, atau bisa comment di thread bersangkutan. Begitu juga sebaliknya. Biasanya kalau yang ngirim PM itu TS yang mau bikin thread di forum R3, kalau pengaduan ada kaskuser yang melanggar aturan biasanya lebih banyak melalui comment di thread dengan menyertakan linknya, kalau ada usulan juga gitu, bisa comment di thread bersangkutan" (wawancara dengan Andrew Pradana, Regional Leader Kaskus Regional Riau Raya, 21 September 2013).

Kaskuser memiliki tingkatan pangkat tertentu sesuai dengan jumlah post (komentar 
dalam sebuah thread) yang dibuat, antara lain newbie (anggota baru dengan jumlah postingan 0-99), kaskuser (100-499), aktivis kaskus (500-749), kaskus holic (750-999), kaskus addict (1.000-3.999), kaskus maniak (4.000-9.999), kaskus geek (10.000-24.999), kaskus freak (25.000-49.999), dan made in kaskus (>50.000). Dengan memenuhi persyaratan yang sudah ditetapkan sebelumnya, kaskuser Regional Riau Raya melakukan kegiatan virtual, yaitu berupa online communication, dengan kedudukan yang sama tanpa ada batasan ataupun jenjang yang terjadi, meskipun secara struktural mereka memiliki tingkatan-tingkatan tertentu.

\section{Pesan-Pesan yang Dipertukarkan dalam Komunikasi Kelompok Komunitas Virtual Kaskus Regional Riau Raya}

Komunikasi virtual, yang biasa juga disebut dengan komunikasi online, merupakan komunikasi yang dilakukan dengan perantara media online atau internet. Dalam komunikasi ini siapapun dapat bertukar pesan satu sama lain tanpa terhalang oleh jarak, selama terhubung dengan akses internet. Menurut Cangara (2007) bahwa pesan dapat disampaikan dengan cara tatap muka atau melalui media komunikasi. Isinya bisa berupa pengetahuan, hiburan, informasi, nasihat, atau propaganda.

Komunitas Kaskus Regional Riau Raya, yang sejatinya merupakan komunitas online, memanfaatkan dengan baik jejaring sosial yang ada untuk berkomunikasi satu sama lain.
Mereka melakukan komunikasi virtual di situs "kaskus.co.id", melalui thread-thread yang diposting dalam Forum Kaskus Regional Riau Raya, yang nantinya hasil dari tukar-menukar pesan tersebut juga akan dishare di akun twitter @KaskusRiauRaya, dan akun facebook KaskusR3.

Forum diskusi adalah tempat untuk mendiskusikan topik-topik tertentu yang menarik bagi anggota Komunitas Kaskus Regional Riau Raya. Pesan-pesan yang dipertukarkan dalam forum diskusi ini berupa informasi perkembangan pengetahuan dan teknologi komunikasi, sharing atau berbagi cerita dengan kaskuser lain, penyelesaian tugas, informasi perencanaan kegiatan, informasi pengaduan. Beberapa bentuk pesan atau informasi dipertukarkan dalam forum dikusi Kaskus Regional Riau Raya tampak pada gambar 2.

Dalam pelaksanaannya kegiatan jual beli di forum Jual Beli Kaskus Regional Riau Raya, dengan izin dan pengawasan regional leader. Produk yang diperjualbelikan tidak boleh melanggar aturan yang berlaku, seperti menjual barang-barang terlarang, ilegal, dan lain sebagainya. Dalam tataran konsep komunikasi, maka secara sederhana dapat dilihat bahwa komunikasi hakikatnya adalah suatu proses interaksi simbolik antara pelaku komunikasi. Terjadi pertukaran pesan (yang pada dasarnya terdiri dari simbolisasisimbolisasi tertentu) kepada pihak lain yang diajak berkomunikasi tersebut.

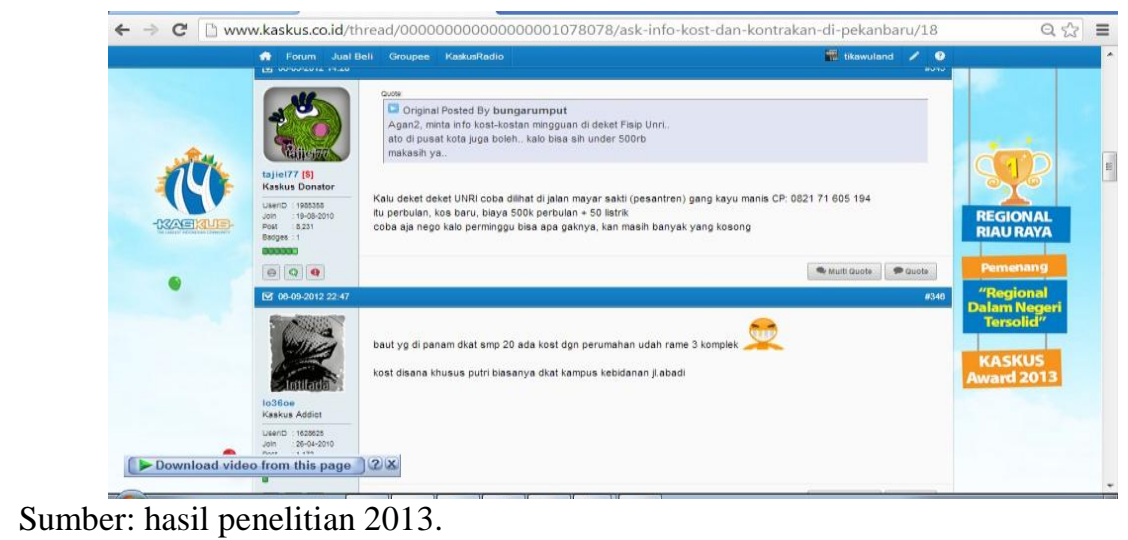

\section{Gambar 2 \\ Kaskuser Regional Riau Raya Berbagi Informasi kepada Kaskuser Lain yang Sedang Membutuhkan}




\section{Pola Interaksi Kelompok di Komunitas Kaskus Regional Riau Raya}

Interaksi sosial adalah merupakan hubungan-hubungan sosial yang dinamis yang menyangkut hubungan antara orang perorangan, antara kelompok-kelompok manusia, maupun antara orang perorangan dengan kelompok manusia. Sedangkan esensi dari interaksi adalah pemaknaaan bersama terhadap nila-nilai, norma, kebiasaan, dan sikap-sikap. Di dalam interaksi itu, hubungan ini bersifat resiprokal, dinamis, dan dialektis (Suparno, Sosiawan, Tripambudi, 2012).

Dalam realitas interaksi sosial Komunitas Kaskus Regional Riau Raya, untuk menunjukkan dan memertahankan kekeluargaan antaranggota, anggota Kaskus Regional Riau Raya tidak hanya berinteraksi di dunia maya tetapi juga di dunia nyata. Dengan kata lain mereka melakukan komunikasi melalui dua bentuk, yaitu dengan komunikasi virtual (online communications), dan komunikasi tatap muka/face to face communications dalam hal ini disebut juga (offline communications).

Komunikasi virtual dilakukan pada saat melakukan kegiatan-kegiatan online dengan media jejaring sosial, seperti facebook, dan twitter, serta melalui forum online di situs kaskus.co.id. Menggunakan situs jejaring sosial adalah berarti melakukan komunikasi virtual yang secara kontekstual ruang dan jarak bersifat virtual, namun ekstasi dalam pemanfaatannya tidak berbeda jauh dengan komunikasi nyata (Sosiawan, 2011).

Dalam berkomunikasi, para kaskuser menggunakan ragam bahasa tertentu yang berbeda dengan bahasa sehari-hari yang lebih dikenal ragam bahasa kaskus (RBK). Ragam bahasa ini merupakan campuran dari berbagai bahasa, misalnya bahasa Indonesia, bahasa Inggris, bahasa-bahasa daerah, ditambah beberapa istilah baru yang digunakan untuk menyatakan suatu hal yang ditunjukkan tabel 2. Pada dasarnya, RBK merupakan bagian dari bahasa gaul atau prokem atau slank yang memiliki kesan santai dan tidak kaku. Selain itu mereka juga memanggil nama kaskuser lainnya dengan menggunakan Kaskus ID masing-masing, meskipun mereka saling mengetahui nama asli masing-masing kaksuser. Dengan demikian membuat mereka merasa semakin dekat satu sama lain.

Interaksi tatap muka akan berlangsung ketika Komunitas Kaskus Regional Riau Raya melakukan kegiatan-kegiatan offline. Kegiatan yang dilakukan oleh Kaskus Regional Riau Raya dibagi menjadi dua, yaitu: kegiatan formal dan kegiatan informal. Beberapa kegiatan formal yang dilakukan oleh komunitas ini pada tahun 2013 antara lain: donor darah yang dilakukan rutin sekali tiga bulan.

Pada kegiatan formal, Kaskus Regional Riau Raya umumnya tidak bekerja sendiri, melainkan bekerjasama dengan berbagai pihak pendukung. Sedangkan kegiatan informal lebih mengarah pada kegiatan rutin ringan seperti berkumpul untuk mempererat tali persaudaraan antarkaskuser, seperti: mini gathering yang dilakukan setiap bulannya di Warung Melati 21, nonton bareng, CFD (Car Free Day), dan lain-lain.

Dalam komunikasi tatap muka, para kaskuser melakukan interaksi dengan penggunaan bahasa yang akan mereka maknai

Tabel 2

Ragam Bahasa Kaskus (RBK)

\begin{tabular}{cc}
\hline RAGAM BAHASA KASKUS & ARTI \\
\hline Ane & Saya \\
Agan & Juragan \\
Pertamax & Pertama kali \\
Afgan & Sadis \\
Cendol & Reputasi bagus \\
Bata merah & Reputasi buruk \\
Gajebo & Gak jelas bo' \\
\hline
\end{tabular}

Sumber: hasil penelitian 2013. 
sama halnya dengan ragam bahasa ketika mereka melakukan komunikasi virtual. Lebih unik lagi tak jarang ketika bertegur sapa secara tatap muka pun para kaskuser. Kaskuser Regional Riau Raya lebih nyaman untuk menggunakan ID Kaskus untuk menyapa rekan sesama kaskuser sampai saat ini. Seno misalnya, dengan alasan lebih merasakan kedekatan satu sama lain dengan menyapa menggunakan ID Kaskus, ia memilih untuk tetap menggunakan nama itu ketika berbincang dengan kaskuser lain, meskipun tidak selalu ia gunakan di setiap kesempatan.

Interaksi yang terjadi antarkaskuser Regional Riau Raya dapat terjadi dengan siapa saja antaranggota, yaitu antarregional leader, aktivis regional, maupun kaskuser biasa. Meskipun memiliki tingkatan, tapi mereka dapat berkomunikasi secara langsung satu sama lain tanpa harus melalui perantara komunikator lain, baik ketika online maupun offline. Dengan berbagai tujuan yang ingin mereka capai dalam melakukan komunikasi virtual di forum Kaskus Regional Riau Raya, dengan tidak adanya jenjang apapun, membuat anggota komunitas ini memiliki kenyamanan tersendiri di dalamnya. Mereka dapat berbagi serta mendapatkan informasi yang mereka inginkan, berbagi cerita apapun, tak hanya berbincang melalui media online tapi juga berbagi cerita di dunia nyata. Hal ini menunjukkan adanya interaksi secara terusmenerus antarkaskuser.

Dalam interaksi, apabila seseorang tertarik pada orang lain, maka ia akan mengadakan interaksi dengan orang yang bersangkutan (Walgito, 2007). Sebaliknya, jika seseorang tidak tertarik, maka ia tidak akan tertarik mengadakan interaksi. Sebelum suatu kelompok dapat dikatakan sebagai kelompok yang kohesif, perlu melalui ketertarikan kelompok (interpersonal attraction). Dengan demikian unsur ketertarikan (attractiveness) seseorang akan turut menentukan terjadinya interaksi. Dengan kata lain, ketertarikan secara tidak langsung berpengaruh pada kohesivitas (cohesiveness) kelompok, yaitu melalui interaksi.

\section{Kohesivitas Kelompok Komunitas Kaskus Regional Riau Raya}

Kohesivitas merupakan kekuatan interaksi dari anggota suatu kelompok. Kohesivitas ditunjukkan dalam bentuk keramahtamahan antaranggota kelompok, mereka biasanya senang untuk bersama-sama. Masing-masing anggota merasa bebas untuk mengemukakan pendapat dan sarannya. Anggota kelompok biasanya juga antusias terhadap apa yang ia kerjakan dan mau mengorbankan kepentingan pribadi demi kepentingan kelompoknya. Merasa rela menerima tanggung jawab atas aktivitas yang dilakukan untuk memenuhi kewajibannya. Semua itu menunjukan adanya kesatuan, kereratan, dan saling menarik dari anggota kelompok (Wiryanto, 2005).

Begitu juga yang terjadi dalam Komunitas Kaskus Regional Riau Raya, ada keramahtamahan antarkaskuser, mereka senang berkumpul dan bersama-sama, setiap kaskuser memiliki kebebasan untuk mengemukakan pendapat dan sarannya, setiap kaskuser juga antusias terhadap apa yang ia kerjakan untuk komunitasnya, serta menerima tanggung jawab atas aktivitas yang dilakukan untuk memenuhi kewajibannya dan kewajiban bersama. Kohesivitas yang terbentuk dalam komunitas ini, sedikit banyak dipengaruhi oleh keanggotaan dan peran setiap kaskuser dalam komunitas, adanya tradisi dan kebiasaan baik itu dalam berkomunikasi maupun berinteraksi, adanya spesialisasi fungsi (pelaksanaan tugas) yang diwujudkan dalam bentuk struktur, adanya kesadaran setiap kaskuser tentang bagaimana caranya ia berfungsi dan bagaimana struktur dalam komunitas ini, serta adanya keterikatan (attachment) kepada komunitas yang terbangun dari interaksi dan komunikasi antar anggota di dalamnya.

\section{Norma Kelompok Komunitas Virtual Kaskus Regional Riau Raya}

Norma dalam kelompok mengidentifikasi anggota kelompok itu berperilaku. Norma-norma kelompok di sini adalah pedoman-pedoman yang mengatur tingkah laku individu dalam suatu kelompok. Pedoman ini sesuai dengan rumusan tingkah 
laku yang patut dilakukan anggota kelompok apabila terjadi sesuatu yang bersangkut paut dengan kehidupan kelompok tersebut (Huraerah, Abu, dan Purwanto, 2006). Pengembangan norma dalam suatu kelompok digunakan untuk mengatur perilaku kelompok. Norma ini berlaku bagi anggota secara individu maupun keseluruhan.

Tiap kelompok menerapkan sistem nilai. Norma kelompok ini akan menjadi norma individu. Jika dalam kehidupan seharihari seseorang terikat oleh banyak nilai dan aturan yang berlaku di masyarakatnya, maka di dunia maya yang bersangkutan lebih memiliki kebebasan walaupun ada juga nilainilai dan aturannya akan tetapi umumnya lebih longgar atau lebih umum (Maryani, 2012). Pada interaksi dunia maya Kaskus Regional Riau Raya memunyai aturan untuk anggotanya dalam berposting yang baik. Bagi kaskuser yang melanggar aturan-aturan atau rules tersebut, konsekuensinya bisa saja postingan yang menyalahi aturan tersebut tiba-tiba hilang (dihapus oleh admin), bahkan kaskuser yang membandel harus menerima konsekuensi yakni tidak bisa menggunakan ID nya lagi. Aturan-aturan tersebut antara lain ditunjukkan tabel 3.

Tidak ada aturan formal dalam komunitas ini untuk hal komunikasi, seorang anggota dapat berkomunikasi dengan siapapun, selama apapun, asalkan tidak melanggar aturan serta norma kesopanan yang berlaku, saling menghormati, serta tentunya tetap menghargai adanya keberadaan seorang pemimpin.

Tabel 3

Rules (Aturan) Post/ Thread/ Topic Regional Riau Raya

\begin{tabular}{cc}
\hline No & Aturan-aturan Komunikasi Virtual Kaskus Regional Riau Raya \\
\hline 1 & Dalam satu regional hanya terdapat satu lounge umum tempat kaskuser chit chat, yaitu
\end{tabular}
di Dermaga. Di sini teman-teman bisa ngobrol, sharing, dan lain-lain.

2 Gunakanlah prime ID selama berposting, dan jika menggunakan ID Clone harap menggunakan avatar prime ID nya atau menyantumkan prime ID nya pada about me di halaman profil. Tapi ada baiknya lebih terbuka kepada kaskuser lain, demi kenyamanan dan kekeluargaan di R3. Buat teman-teman yang merasa ada ID Clone yang menganggu, bisa $P M$ regional leader beserta alasannya, sehingga bisa dicari solusinya.

3 Hindari post atau membuat thread yang bersifat SPAM, Flame, Junk Posting, dan sebagainya. Janganlah mengotori rumah kita sendiri. Jaga dan rawat forum regional kita ini.

4 Janganlah menggunakan kata-kata SARA dan mengandung pornografi. Kata-kata tidak sopan, penghinaan terhadap anggota lain, ataupun yang sejenis yang bisa mengakibatkan konflik antarkaskuser. Ada baiknya lebih mendahulukan kepentingan bersama.

5 Jika ingin ikut dalam jual beli, bisa langsung masuk ke online store Regional Riau Raya dengan mengikuti peraturan yang sudah dibuat di page one tersebut. Selain bisa jual beli, kita bisa silaturahmi untuk menghindari penipuan.

6 Diharapkan seluruh anggota bisa dan mau berpartisipasi di forum dengan cara posting di thread yang ada dan juga aktif pada kegiatan-kegiatan offline yang sudah kita agendakan 


\section{PENUTUP}

\section{Simpulan}

Peran pelaku komunikasi kelompok dalam Komunitas Virtual Kaksus Regional Riau Raya disesuaikan dengan struktur dan tingkatan yang ada baik sebagai Regional Leader, Aktivis Regional, dan Anggota Kaskus Regional. Regional Leader selain berperan besar dalam pengambilan keputusan, juga berwenang membantu menyelesaikan konflik dan membangun hubungan baik antar Kaskuser Regional Riau Raya.

Komunitas Virtual Kaskus Regional Riau Raya pada dasarnya merupakan forum diskusi dan forum jual beli. Pesan-pesan yang tersampaikan dan dipertukarkan dalam Komunitas Kaskus Regional Riau Raya adalah berbagi informasi seputar pengetahuan baru dari kaskus, baik itu menyangkut internal Komunitas Kaskus Regional Riau Raya maupun mengenai eksternal berupa berbagi cerita atau sharing dengan kaskuser lainnya, informasi penyelesaian tugas, informasi perencanaan kegiatan, informasi tentang pengaduan, informasi jual beli, dan informasi seputar event organizer.

Interaksi sosial yang terjalin di Komunitas Kaskus Regional Riau Raya tidak hanya berlangsung secara online tetapi juga offline melalui berbagai kegiatan untuk menujukkan eksistensinya kepada lingkungan dan memertahankan kekeluargaan antar anggota. Kegiatan yang dilakukan di antaranya kegiatan formal dan informal. Semakin sering kegiatan dilakukan maka semakin banyak interaksi terjadi, semakin banyak interaksi yang terjadi menyebabkan ketertarikan di antara anggota-anggotanya juga semakin besar. Suasana hangat, tidak kaku, santai, dan kekeluargaan membuat kaskuser merasa nyaman berada di dalam komunitas ini. Kohesivitas di Komunitas virtual Kaskus Regional Riau Raya terbentuk di antara Kaskuser melalui intensitas interaksi yang terjadi dalam bentuk online dan offline communication. Pada produktivitas kelompok, kaskuser akan memberikan kontribusi kepada kelompoknya dengan selalu memberikan dukungan moral dengan cara selalu hadir pada online dan offline communication. Norma yang diberlakukan di Komunitas Kaskus Regional Riau Raya pada dasarnya adalah norma sehari-hari yang biasa diterapkan dalam kehidupan sosial yaitu lebih kepada norma-norma pergaulan dan kesopanan.

\section{Saran}

Diharapkan sebagai anggota dalam sebuah komunitas virtual, seseorang juga dituntut cerdas, bertanggungjawab, dan selektif dalam memberikan ataupun dalam memilih informasi. Komunitas virtual bisa terus menjadi ajang bertukar pikiran dan mengembangkan wawasan serta pengetahuan tanpa mengenal batas waktu dan tempat.

\section{DAFTAR PUSTAKA}

\section{Buku:}

Bungin, Burhan. (2008). Sosiologi Komunikasi.Komunikasi (Teori, Paradigma, dan Discourse Teknologi Komunikasi di Masyarakat). Jakarta: Kencana Prenada Media Group.

Cangara, Hafied. (2007). Pengantar Ilmu Komunikasi. Jakarta: PT. Raja Grafindo. Persada.

Derry, Sharon J. (2005). Interdisciplinary Collaboration:an Emerging Cognitive Science. New Jersey: Lawrence Erlbaum.

Huraerah, Abu dan Purwanto. (2006). Dinamika Kelompok: Konsep dan Aplikasinya. Bandung: PT Rafika Aditama.

Mulyana, Deddy. (2008). Ilmu Komunikasi Suatu Pengantar. Bandung: PT Remaja Rosdakarya.

(2010). Metode Penelitian Kualitatif:Paradigma Baru Ilmu Komunikasi dan Ilmu Sosial Lainnya. Bandung: PT Remaja Rosdakarya .

Muslimin. (2010). Teknologi Media Modern dan Upaya Mempertahankan Kebudayaan. Jakarta: Erlangga.

Moleong, Lexy J. (2008). Metodologi Penelitian Kualitatif. Bandung: PT Remaja Rosdakarya Offset. 
Nasrullah, Rully. (2012). Komunikasi Antar Budaya di Era Budaya Siber. Jakarta: Kencana Prenada Media Group.

Rheingold, H. (1993). The Virtual Community : Homesteading on the Electronic Frontier.Reading; Addison-Wesley.

Wood, Andrew F.and Matthew J. Smith, (2005). Online Communication:

Linking Technology, Identity, and Culture, Mahwah. New Jersey: Lawrence Erlbaum Associates.

Profile Kaskus Regional Riau Raya (R3). (2013). Pekanbaru: Kaskus R3

Spaulding, A.D and Hagn, G.H. (2009). "On the definition and estimation of spectrum occupancy", IEEE Transactions on Electromagnetic Compatibility, EMC- 19(3).

Walgito, Bimo. (2007). Psikologi Kelompok. Yogyakarta: Andi Publisher.

Wiryanto. (2005). Pengantar Ilmu Komunikasi. Jakarta: Gramedia Widiasarana Indonesia.

Wenger, E. (et.al.). (2002). Cultivating communities of practice: a guide to managing knowledge. Boston: Harvard Business School Press

West, Richard and Lynn H. Turner. (2008). Pengantar Teori Komunikasi: Analisis dan Aplikasi. Buku 1 Edisi ke-3 Terjemahan Maria Natalia Damayanti Maer. Jakarta: Salemba Humanika.

\section{Jurnal:}

Maryani, Eni dan Hadi Suprapto Arifin. (2012) Kontruksi Identitas Melalui Media Sosial. Jurnal Kajian Komunikasi BandungVol. 1 No. 1 (Desember 2012), hal.1-92.

Merlina, Tina .(2013). Verbal and Visual Expression of Emotions on Kaskus : A Semiotic Study. Jurnal Mimbar Bandung Vol. 29 No.1 (Juni 2013), hal.1-122.

Khairil, Muhammad. (2012) Perilaku Komunikasi Terpidana Kelompok Terorisme. Jurnal Ilmu Komunikasi
Yogyakarta Vol.10, No. 2, (Agustus 2012), hal. 105-249.

Sosiawan, Edwi Arif. (2011) Penggunaan Situs Jejaring Sosial sebagai Media Interaksi dan Komunikasi di Kalangan Mahasiswa. Jurnal Ilmu Komunikasi Yogyakarta Vol.9 No. 1, (Januari-April 2011), hal.60-75.

Suparno, Basuki Agus., Sosiawan, Edwi Arif.,dan Tripambudi, Sigit. (2012). Computer Mediated Communication Situs Jejaring Sosial dan Identitas Diri Remaja. Jurnal Ilmu Komunikasi Yogyakarta Vol. 10, No 1, (Januari April 2012), hal. 1-104.

\section{Skripsi:}

Diradametha, N. (2009). Pembentukan Identitas Pada Komunitas Virtual: Studi Kasus Komunitas Virtual ArchAngel. Skripsi. Jakarta: Universitas Indonesia

Ichwanudin. (1998). Hubungan Perilaku Komunikasi Peserta Kelompok Penggerak Pariwisata (Kompepar) dengan Adopsi Program Sapta Pesona di Kabupaten Sukabumi, Skripsi. Bogor: Institut Pertanian Bogor (IPB).

\section{Internet:}

Pramiyanti , Alila dan Christin, Maylanny. (2014). Makna Simbol Emotikon dalam Komunitas Kaskus.Jurnal Sosioteknologi, Vol. 13, No. 2 (Agustus 2014). Tersedia dalam: <http://journal.fsrd.itb.ac.id/jurnaldesain/pdf_dir/issue_3_13_2_6.pdf $>$ dia kses 31 Oktober 2014.

Susilo, Devina. (2011).Proses Interaksi Pada Komunikasi Kelompok Virtual Global A-Melody. Digital Collections Petra Christian University. Tersedia dalam: <http://dewey.petra.ac.id/catalog/ft_vie wer.php?fname=jiunkpe/s1/ikom/2011/j iunkpe-ns-s1-2011-51407106-24294interaction_process-abstract_toc.pdf: >diakses 24 Agustus 2014. 